\title{
LIPOMA OF THE MIDBRAIN
}

\author{
POS'T-MORTEM FINDING IN A PATIENT WITH BREAST CANCER
}

VERONICA MAIA GOUVEA *- MYRIAM DUMAS HAHN ** - LEILA CHIMELLI**

SUMMARY - Intracranial liponias are rare, usually do not have clinical expression and are located more frequently in the corpus callosum. Other lucations include the spinal cord, midbrain tectum, superior vermis, tuber cinereum, infundibulum and more rarely cerebellopontine angle, hypothalamus, superior medullary velum and insula. We report the case: of a lipoma of the left inferiur colliculus which was a post-mortem finding in a woman who died of breast cancer. Although there are reports of intracranial lipomas in patients with malignant tumors there is no explanation for the co-existence of the two tumors. The present tumor also includes a segment of a nerve which is not uncommon, but a less common finding was the presence of uests of Schwann cells within it, shown by immunohistochemistry.

Lipoma do nesencéfalı: uchudo de necróysia em paciente com câncèr du mama.

RESUMO - Lipomas intracranianos são raros, em gedal sem expressăo clinica, localizadus mais freqüentemente no corpo caloso. Outras localizacões incluem medula espinhal, teto mesencefálico, vermis superior, tuber cinereum, infundibulum e mais raramente o angulo ponto-cerebelar, hipotálamo, véu medular superior e insula. Relatamos o achado de necrópsia de um lipoma do colículo inferior esquerdo em una mulher com câncer de mama. Embora haja relatos de lipomas intracranianos em pacientes com tumores malignos nåo há explicaçāo para a co-existência dos dois tumores. O presente tumor também inclui o segmento de um nervo, o que não é incomurn, nias um achado menos comum foi a presença de ninhos de células de Schwann no turnor, mostradas por imuno-histoquínica.

Lipomas are benign tumors which can rarely involve the central nervous system (CNS), the incidence not exceeding $0,5 \%$ of all the intracranial tumors 1,9 . The intracranial lipomas are usually small, well circumscribed 14 and have any age or sex predominance 3 except for the spinal lipomas which predominate in children and young adults 5 . They are located more frequently in the corpus callosum $\mathbf{1 4}, \mathbf{1 5}$, tuber cinereum 14, infundibulum 14, quadrigeminal plate $3,6,14$ and cisterna ambiens. In the last location the lesion may lie on the midbrain tectum and the superior vermis 3,10 . It can also be found within the substance of the brainstem and cerebellum 13 and more rarely in the cerebellopontine angle 3,4, hypothalamus 3 , superior medullary velum 7 and insula 8 .

In the present paper we report the case of a lipoma found in the left inferior colliculus of a woman who died with a breast cancer and multiple metastases. The presence of intracranial lipoma and carcinoma elsewhere in the body has ocasionally been described $2,3,14$. We emphasize the presence of Schwann cells dispersed through the tumor which were shown by immunoperoxidase technique.

University Federal Fluminense, Niterói: * Medical Resident, Division of Clinical Neurology; ** Senior Lecturer, Neuropathologist, Department of Pathology. 


\section{CASE REPORT'}

HFS, a black female, ased 46 years was admitted to the huspital in January 1987 with patholugic iracture of the left humerus due to bone metastasis from an infiltrating: ductal carcinoma of the left breast. The patient coursed with vomits, abdominal distension and died one month later. No neurological or vcular symptoms were described in the clinical history. Laboratory data showed no evidence of neurological disorder. Post-mortem examination showed a large tumor in the left weast (infiltrating ductal carcinoma) with metastases to the liver, peritoneum, epiplon, pleura and left humerus.

Neuropathological findings - Macroscopy: The unfixed brain weighed $1250 \mathrm{~g}$. Leptomeninges were thin and transparent. There was slight atrophy of the frontal gyri. Basal vessels were nornal. On sections the brain and the cerebelium were unremarkable. Transverse sections of the brainstem showed a yellow nodular lesion at the level of the left inferior colliculus measuring $0.5 \mathrm{~cm}$ in diameter (Fig. 1). No metastatic lesion was found in the CNS. Microscopy: Histologic examination of the midbrain showed that the yellow nodule observed macroscopically was a benign tumor consisting of mature adipose cells separated from the nervous tissue by a fibrous capsule (Fig. 1). The tumor included a nerve bundle and some
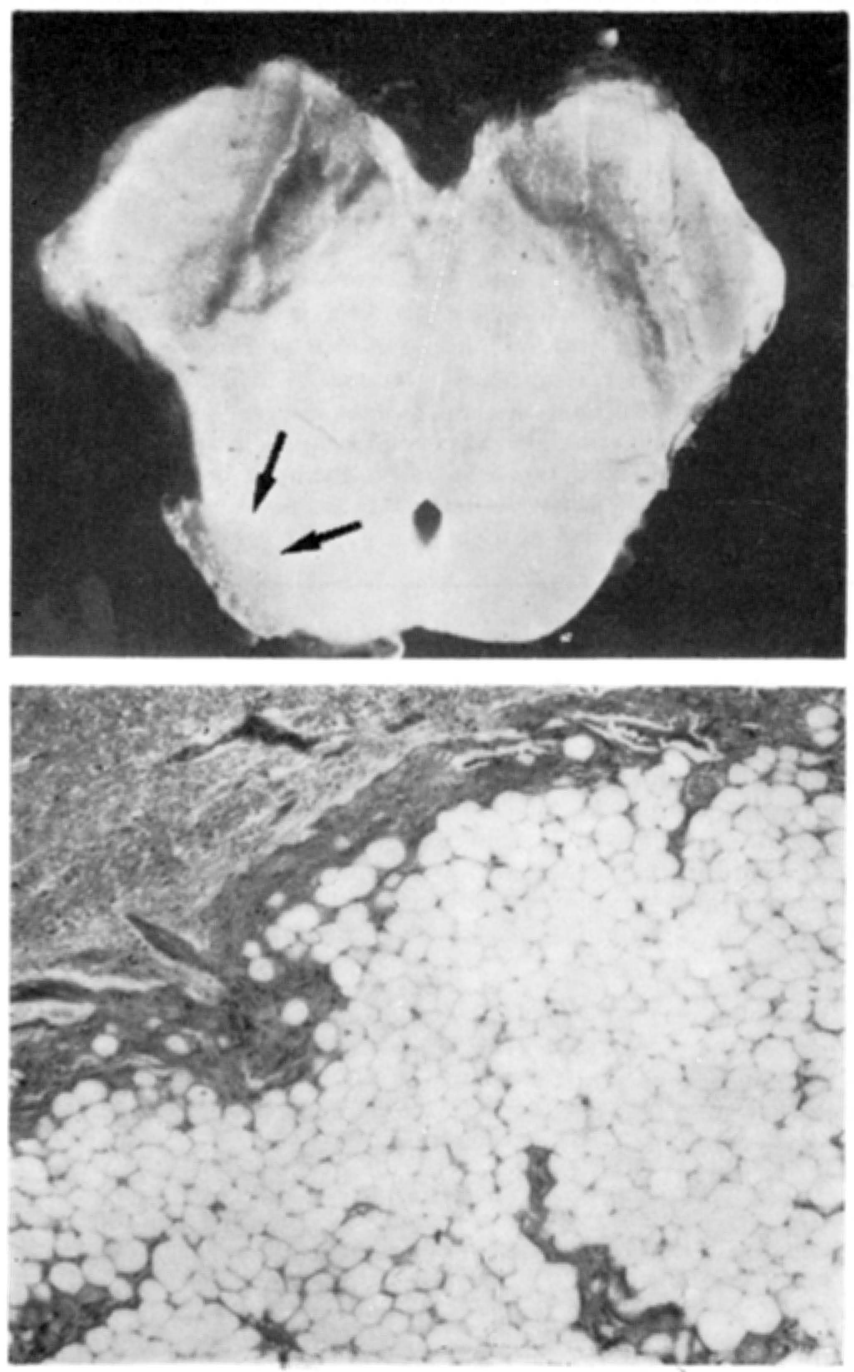

Fig. 1 - Case HFS. Above: Midbrain at the level of the inferior colliculi showing a small lipoma (arrows) partly involving the left inferior colliculus. Below: Histological section of the lipoma characterized by mature adipose cells separated from the adjacent nervous tissue by a fibrous capsule $(H E \times 40)$. 
relatively large blood vessels (Fig. 2). Immunohistochemistry for S100 protein usily the immunoperoxidase technique showed a positive reaction in the nerve bundle as well as in nests of celis interpreted as Schwarn cells, embedded in islands of fibrous tissue inside the tumor (Fig. 2).

Fig. 2 - Case HFS. Above: A nerve bundle (arrow) is included in the lipomit which also contains some blood vessels $(H E \times 100)$. Below: Detail of the lipoma showing some nests of cells positively stained with the immunoperoxidase technique for $S 100$ protein $(\times 400)$.
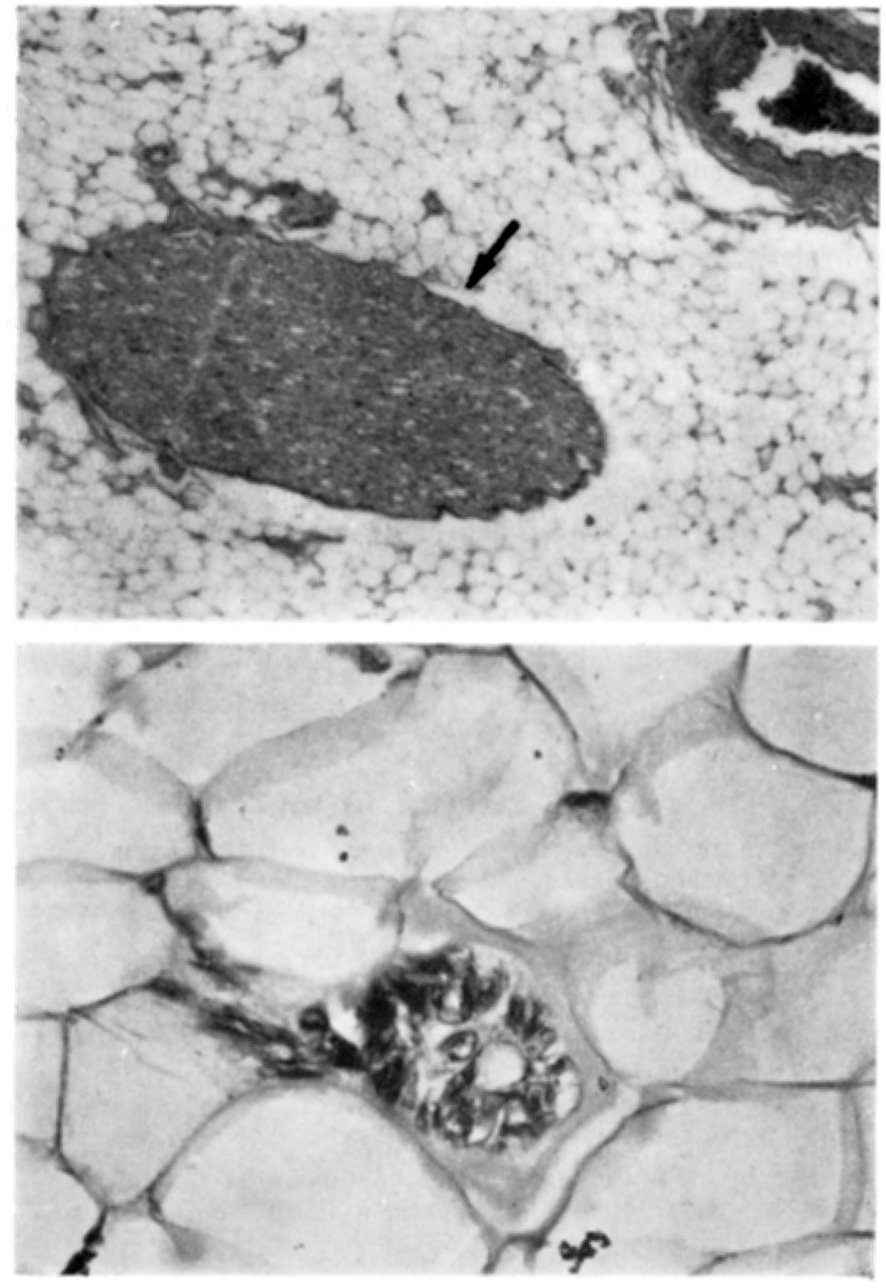

\section{COMMENTS}

Intracranial lipomas are not a frequent finding. Vonderhare \& Niemer 14 reported 4 cases in a series of 5000 autopsies. Only one lipoma was found in 4290 neurosurgical biopsies 3 . More than half of the intracranial lipomas are located in the corpus callosum 15. Since the introduction of CT scan, unexpected findings of intracranial lipomas have increased. The CT diagnosis of a lipoma is based on its very low X-ray attenuation which produces typical images. Only dermoid cysts and teratomas may produce a similar CT appearance 9 . Most of the intracranial lipomas have any clinical expression and they are therefore incidental post-mortem findings 3,14 as in the present case. However, they occasionally induce clinical symptoms which can be directly or indirectly related to the presence of the tumor. In the first case, obstructive hydrocephaly 6 and acoustic nerve lesion 3 have been reported while mental retardation 3,10 and fits 3,12 are usually described in cases in which other CNS dysgenesis like colloid and epidernoid cysts, angiomatosis, cerebellar microdysgenesias and other 
malformaticns co-exist with the lipoma. Intracranial lipomas have also been described in association with extracranial malformations like spina bifida 3,12, cardiac malformation 3,15 and cheilo-gnato-palatoschisis 3 . These dysraphies are however more commonly associated with spinal lipomas 11.

The nerve involved by the tumor is probably the left trochlear nerve although its origin is slightly below the inferior colliculus. The presence of cranial nerves within these tumors is not uncommon 3,7,14, and nests of Schwann cell have rarely been described. They have been considered as branches of the trochlear nerve\%. Unlike the intraspinal lipomas which sometimes infiltrate the nerve roots 5 , the intracranial ones only exceptionally infiltrate the cranial nerves like for example the acoustic leading to vertigo, nystagmus and deafness 3 .

As for the presence of a lipoma in a patient with a breast cancer, we can not correlate the two findings. Reviewing some of the reported cases of lipomas in the midbrain, we found three cases in which a neoplasia was associated with the lipoma: one of them was described by Vonderhare \& Niemer 14 in 1944 and there was a lipoma of the right inferior colliculus in a 45 year ond woman who died of rectosigmoid adenocarcinoma. Budka 3 described a case in which a lipoma was associated with medulloblastoma in a three year old girl who had also mycropolygiria and dysgenesis of the cerebellar nuclei. Another patient described by Bailey and Bucy 2 had a breast cancer with multiple metastases and a lipoma in the region of the quadrigeminal bodies which was an incidental finding at necropsy. In none of these reports was there any comment on the coexistence of lipomas and malignant tumors.

Acknowledgements - We should like to thank Miss Ana Rodrigues and Mr. Heliomar Marcos for technical assistance and Miss Rosely Cunha for the photographic work.

\section{REFERENCE'S}

1. Bailey P - Intrucranial Tumors. Ed 2. Charles C. Thonas, Springfield, 1948.

2. Bailey $P$, Bucy $P C$ - The origin and nature of meningeal tumors. Am J Cancer $15: 15,1981$.

3. Budka $\mathbf{H}$ - Intracranial lipomatous hamartonas (intracranial 'lipomas'): a study of 13 cases including corrbinations with medulloblatoma, colloid and epidermoid cysts, angiomatosis and other malformations. Acta Netropathol 28:205, 1974.

4. Fukai M., Tanaka A, Kitamura $K$, Okudera $T-$ Lipona of the cerebello-pontine angle: case report. J Neurosurs 46:544, 1977.

5. Giuffre R, Gambacorta D - Lipoma of the spinal cord: case report. J Neurosurg $35: 335$, 1971.

6. Halmagyi GM, Evans WA - Lipoma of the quadrigreminal plate causing progressive obstructive hydrocephalus. J Neurosurg $49: 453,1978$.

7. Hara M, Kawachi S, Hirano A - Lipoma of the superior medullary velum with Schwann celis: report of a case and review of the literature. Acta Pathol Jpn 31:825, 1981.

8. Hatashita S, Sakakibara $T$, Ishii $\mathbf{S}$ - Lipoma of the insula. J Neurusurg 58:300, 1983.

9. Kazner E, Stochdorph $O$, Wende $S$, Grumme $\mathrm{T}$ - 1ntracranial lipoma: diagnostic and therapeutic considerations. J Neurosurg 52:234, 1980.

10. Koehi RH, Solitare GB, Heffner RR Jr - Lipomatous hamartoma involving the midbrain and cerebellum of a mentally retarded man. $J$ Ment Defic Kes 14:22\%, 1970.

11. Rogers HM, Long DM, Chou SN, French LA - Lipomas of the spinal cord and cauda equina. J Neurosurs $34: 349,1971$.

12. Sabouraud O, Pecker J, Simon $P$, Chatel $M \rightarrow$ Lipomes du corps calleux: données angiographiques et discussion pathogenique de leur semiologie clinique. Rev Neurol $117: 557,1967$.

13. Schmid $A H-A$ lipoma of the cerebellum. Acta Neuropathol 26:75, 1973.

14. Vonderahe AR, Niemer WT - Intracranial lipoma: a report of four cases. J Neuropathol Kxp Neurol $3: 344,1944$.

15. Zettner A, Netsiky MG - Lipoma of the corpus callosum. $J$ Neuropathol Exp Neurol $19: 305,1960$. 